\title{
Visual Semiotics Analysis on Television Ads UHT Ultra Milk "Love Life, Love Milk"
}

\author{
Peter Ardhianto ${ }^{\mathrm{a}, 1, *}$ William Manuel Son ${ }^{\mathrm{b}, 2}$ \\ a Visual Communication Design Program, Soegijapranata Catholic University, Indonesia. \\ ${ }^{\mathrm{b}}$ Visual Communication Design Program, Soegijapranata Catholic University, Indonesia. \\ ${ }^{1}$ peter.ardhianto@unika.ac.id *; ${ }^{2}$ williammanuelson@gmail.com
}

\section{ARTICLE INFO}

Article history

Received 2019-05-02

Revised 2019-06-04

Accepted 2019-05-29

Keywords

Visual

Semiotic

TVC

Ads

Design

\section{AB STRACT}

The number of adverts that have sprung up this digital era has made the creative industry try to break new breakthroughs so that advertisements can be more able to get the attention of the audience by making many innovations. As in the uht ultra love life love milk television television ad. What is applied to television advertising media that has a general target for all people who see this ad, and the main target is young people because it is more relevant and consumers are mostly young people, because milk supports the development period. The purpose of this study is to help review the meaning of a modern advertisement, especially milk advertisements which are usually for children but aimed at all ages.This study uses Roland Barthes's semiotic theory as a theory in the study of television ads, with methods of documentation, interviews, literature studies, so that the right data is collected to be analyzed. So the conclusion in this study is that uht ultra love live love milk television advertising has the message contained in each video scene that is combined with verbal text emphasis and changes in typographic elements that have their own meaning to trigger emotions from consumers

This is an open access article under the CC-BY-SA license.

\section{Introduction}

In the era of technological developments and markets, it is inevitable that producers will emerge unique and new ways to promote their products, so that consumers do not feel bored and do not turn to other producers. In addition to providing sales innovations both in packaging and in the way of sales, advertising is also still a means to convey innovations that are made and can attract the attention of consumers, both old and new consumers. So that it can raise the level of promotion of these products Television advertising is one of the advertising media that is still in great demand by producers in Indonesia, to sell their products or promotions for these products, television advertising is also used as conventional media by manufacturers to market and promote products, and a means to convey the message to the product that is conveyed by producers to consumers.

One of commercial television advertisement that released in 2018 and has begun to spread on television and YouTube is an advertisement for UHT ultra milk "Love Life, Love Milk", which lasts for 1 minute consisting of 34 scenes, the advertisement describes a balanced life by drinking a milk, with a fairly broad target market from children to the elderly, which is symbolized by their advertising model that uses small children to parents, and uses soft selling techniques, which are packaged in these 1-minute ads. Ultra UHT milk itself is a product of ultrajaya milk industry. The one who produces drinks, initially from a home industry, which was founded in 1958 later became a company in 1971. 
The novelty of Ultra Milk UHT advertisements in 2018 are the emergence of visual emphasis and verbal text on each scene, which is considered only ordinary, but needs deep meaning to be able to understand the meaning of the visual verbal text of the ad, and many use models ranging from children small to parents, who are carrying out activities that vary according to their age, and at the end of the section appears the Ultra UHT Milk visual as an object marketed through the ad, which essentially lives from small children to the elderly, any hobby is definitely will be achieved, and will be balanced if you maintain health by drinking milk.

The television advertising is really interesting because the value that is conveyed through visual and verbal texts that are in harmony, and describe balance in life, boldly carrying out new challenges and also opportunities that exist in life. And balanced by drinking milk, this ad is very creative and modern. The combination of text and visual activity in the image is also appropriate. Therefore semiotic analysis is used to examine the meaning of this advertisement.

The purpose of this study is to bridge the target of advertising with advertisers in conveying deep meaning in the ad "Love Life, Love Milk". The assessment carried out is to examine the visuals of a scene and text in an advertisement, the selection of scenes is based on the transfer of stories from this advertisement.

\section{Method}

\subsection{Documentation}

Is data retrieval by providing document documents relating to the object of research. And in this study the document is in the form of pictures of each scene contained in the advertisement of UHT Ultra Milk "Love Life, Love Milk" which later can facilitate data analysis.

\subsection{Literature review}

Is part of a scientific paper that contains discussions of previous research and scientific references related to the research being carried out. Whether it's from encyclopedias, journals, books, or the internet related to the object of research. In this study the author takes data from scientific articles, books and website sources from the internet to assist in the data processing.

\subsection{Content analysis}

Is a way to analyze a data systematically so that it is easily understood and described. In this study the author described the video advertisement into pieces of each scene to make it easier to analyze the Roland Barthes semiotic technique.

\subsection{Interview}

Is a way to get data and information by asking the respondent or resource person. In this study the author conducted an interview with the audience of the ad and the ad design team so that they got data from two viewpoints, then analyzed the results.

\section{Result and Discussion}

\subsection{Advertisement}

According to (Verlegh, Peeter \& Fransen, Marieke \& Kirmani, 2015), argued that advertising is a form of non-personal communication that sells persuasive messages from clear sponsors in order to influence people to buy products by paying costs for the media used. Duncan added that advertising should also have an outside reach, creating brain awareness and building an image on the target (Duncan, 2005: 10). In the advertisement of UHT Ultra Milk "Love Life Love Milk" also has the right image for the target, through the models and activities carried out in the adverstising. From some of the meanings of the ads above, advertising itself is basically a media communicator between producers and consumers to persuade consumers to try or use products offered persuasively.

\subsection{TVC}

TVC is Commercial Television or television advertising. One channel of communication that currently has a competitive advantage and is even able to shift the role of other mass media in reaching in the field of advertising is television (Lal, Ruhi \& Vats, 2016: 60). This is because the 
speed and attractiveness of the television is made the media to become a choice of companies in communicating its products. In this study the advertisement of UHT Ultra Milk "Love Life Love Milk" also publishes its advertisements via television, because it can be more easily reached by their target market.

TVC is also a tool for producers to attract consumers' attention (persuasive) with a commercial purpose, namely to attract consumers to buy to try or even buy products. And the maximum duration for television advertisements themselves is recommended to be a maximum of 1 minute, because these ads will be seen only at a glance and the opportunity will not be noticed by the audience, therefore ad producers must have a special design plan to take advantage of the time available, so that their ads are attached and easy understood by the people watching. And there is a contradiction of thought. In just seconds the ad has been able to create behavior homogeneity, while other standard television programs by taking a duration of more than 30 minutes are very difficult to form equality of patterns (Sutherland, 2005: 236).

\subsection{Semiotic}

Semiotics comes from Greek (semeion) which means sign. Sign is something that represents something metaphor, the process of representing it occurs when the sign is interpreted, its relation to the one it represents, can be in the form or color. Semiotics is the science of signs that studies social and cultural phenomena. Signs themselves have two aspects namely marker (signifie) and signified. According to Zoest, everything that can be observed or made observable can be called a sign. Therefore, the sign is not limited to objects. There are events, not only in the event that structures are found in something, a habit can all be called a sign (Zoest, 1993: 18). Markers are the formal form of the sign. Whereas the sign is something marked by the marker. In research on the advertisement of UHT Ultra Love Life Love Milk, it will be processed in a visual semiotic about what the message contained in the advertisement is implicit and the meaning of the marker marker in the ad

The semiotic theory suppresses communication as a generation of meaning, then for communication to take place the message must be made in the form of signs. Semiotics is the theory par excellence of the artificial and therefore should have a substantial role in understanding designed phenomena (Holt, 2017: 332). The message will encourage the recipient to build meaning for himself. The advertisement of UHT Ultra Milk "Love Life, Love Milk", also conveyed the message conveyed in visual form, namely with their video scenes that differed in model and verbal text supported by visual elements, which were in harmony with the verbal text so that the message to be conveyed could be conveyed by well.

Understanding the semiotic is divided into two streams, namely the flow that follows the thought of Charles Sanders Peirce, and the second flow that follows the thinking of Ferdinand de Saussure. Peirce with concepts based on firstness, secondness, and thirdness. While Saussure is more pressing on the aspects of language, according to his background, namely as a linguist. And from these two theories do not make divisions or differences of opinion but on the contrary, that is complementary and can be utilized in the world of design (Coelho, Denis \& Figueiredo, 2010: 335).

The Semiotic theories proposed by Zoest, Saussure, Peirce, corroborate this research, but in this study it is more relevant to use Roland Barthes's semiotic theory research which will be the theory of problem solving, becoming a reference for researchers in reviewing Visual Semiotics contained in the advertisements of UHT Ultra Milk "Love Life, Love Milk".

\subsection{Roland Barthes's Semiotics}

In this study, it is relevant to use Roland Barthes's semiotic theory, because it can answer the problem formulation contained in this study, which discusses the advertisement of UHT Ultra Milk "Love Life, Love Milk", to explain the implicit meanings contained in it and to know the elements of the visual elements. Barthes put forward his theory of connotative meaning, that the connotation is used to explain whether one of the three ways of working the sign in the second order order. The connotation describes the interactions that take place, the signs meet the feelings of the users and their cultural values. (Najafi, Farzaneh \& Abbas, 2014: 177).

The method of Roland Barthes is known as a method that criticizes the Saussure semiotic method. Barthes's semiotic method is known as multilevel semiotics which analyzes deeper by relating myths. Barthes's semiotic method, and in this study used in analyzing the advertisement of Ultra Love Life Love Milk UHT Milk to examine the visual elements that have ad text in a scene 
and look for implicit messages to be conveyed through signifier, signified and then examined through denotative, connotative and myth.

\subsubsection{General Identification}

The advertisement that will be studied is the advertisement of UHT Ultra Milk "Love Life, Love Milk" which was published on television as well as YouTube video sites. This ad has a duration of 60 seconds. In this advertisement there are 22 scenes in which there is text that gives emphasis to the message, each scene in the advertisement is connected between the scene and the other scene. This ad uses a sound effect in the form of an up beat music instrument intended to support the visuals displayed in the ad. And this type of advertising is a product promotion advertisement and can also lead to public service advertising. In the visual aspect and taking pictures of this ad is based on outdoor and indoor venues and the cast is doing activities such as cycling, dressing up, relaxing on the porch of the house, singing, etc., adjusted to the elements of the verbal text in the ad. While the actors in this advertisement wear clothes that are in accordance with the roles they play, some of them use ordinary home clothes, employee work clothes, sports clothes. Gender that appears in this advertisement, male and female, all of whom have different ages ranging from 7 years to 60 years, are shown in the shooting and activities they do in the scene.

The storyline in this television advertisement is a forward groove which tells of the first scene which shows a child turning off the alarm until the final clip that appears Ultra UHT Milk dairy products accompanied by verbal text, as far as the author's observation in watching and observing this ad video, UHT Ultra Milk wants to make a milk as a consumption every day that can be consumed until old age because it is efficacious and useful for the body, and becomes a complement to the daily diet, by giving facts and motivational words in the television ads.

\subsubsection{Interview Analysis}

The interview was carried out to the management of the Ultra Milk Instagram account (@mymilk_id) to get information from Ultra Milk regarding the message from the UHT Ultra Milk "Love Life, Love Milk" ad. He said that the essence of the message of the ad was to invite viewers who would later be targeted by consumers, to understand the usefulness of milk in their lives, starting from the time of their children to becoming parents. UHT Ultra Milk contains a lot of good substances needed by the body, both in bone growth and to maintain endurance. So it was emphasized by the existence of video results in the form of visual and also verbal texts stacked on top of the visual video, so as to emphasize the value that was intended to be conveyed implicitly.

The main target in this advertisement according to sources is that young people are still active in doing activities, sports and others and with more joyful advertisement, it will be easier to be caught by young people. In addition to the UHT Ultra Milk "Love Life, Love Milk", the author also conducted an open interview about the opinions of lay people about the advertisement, the meaning and message of what they thought they got from seeing the ad. The following is the result of the author's interview with several speakers, namely a food expert named Indah Pratiwi Mahardhita who said that the ad had the message to maintain a perfect pattern of healthy 5 that can be planted early into old age, with different portions of consuming milk. As well as fostering enthusiasm to achieve an achievement with a strong and persistent effort. The second and third informan named Elma Nora Manuela, and Annete Stephanie Turang were samples of High School students and University students who were the main target of the advertisement, they said that the ad had a message that aroused enthusiasm for achieving aspirations and diligently drinking milk in order to undergo activities everyday with enthusiasm, and healthy to old age. And also mention that this ad is more impressive to young people because it is more interesting and not boring like other ordinary ordinary ads, and attracts attention and is relevant to daily life.

\subsubsection{Semiotic Analysis}

In the table below that will discuss the semiotic meanings of each Ads scene that are important to study. Scene selection is taken from the displacement of different characters or activities, at least 12 scenes will be studied in the form of discussion tables starting from setting the signifier with images scene, then seeing the signified as explaners, followed by a denotative study in descriptive explanation and connotative ways to comprehend profound meanings which is associated with myth in accordance with the target market. 


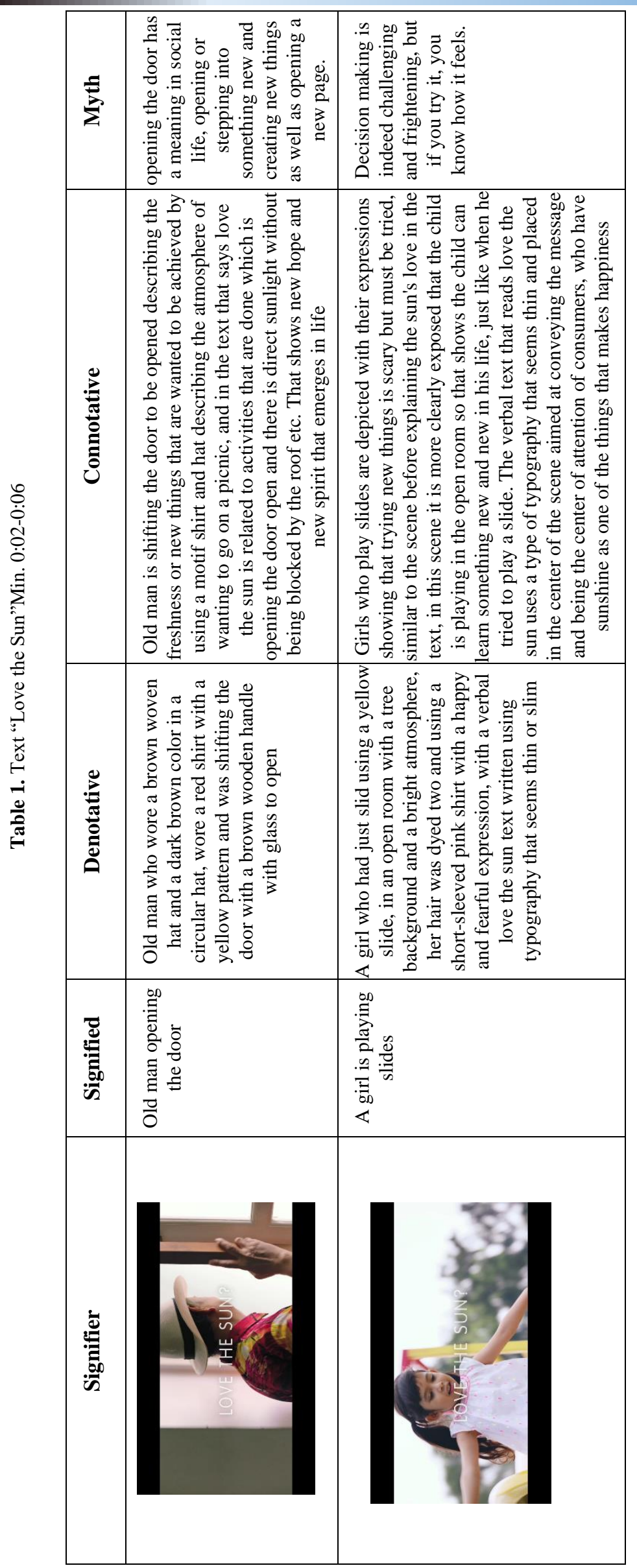




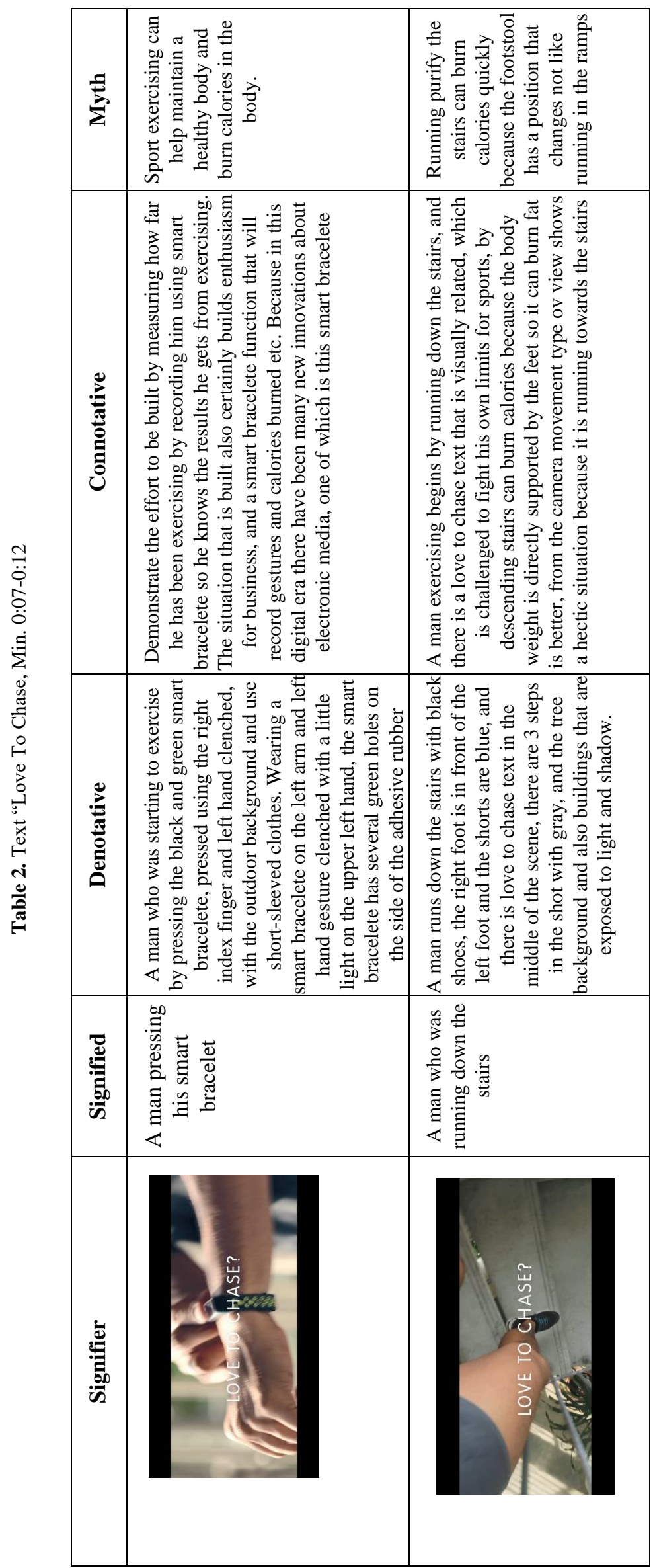




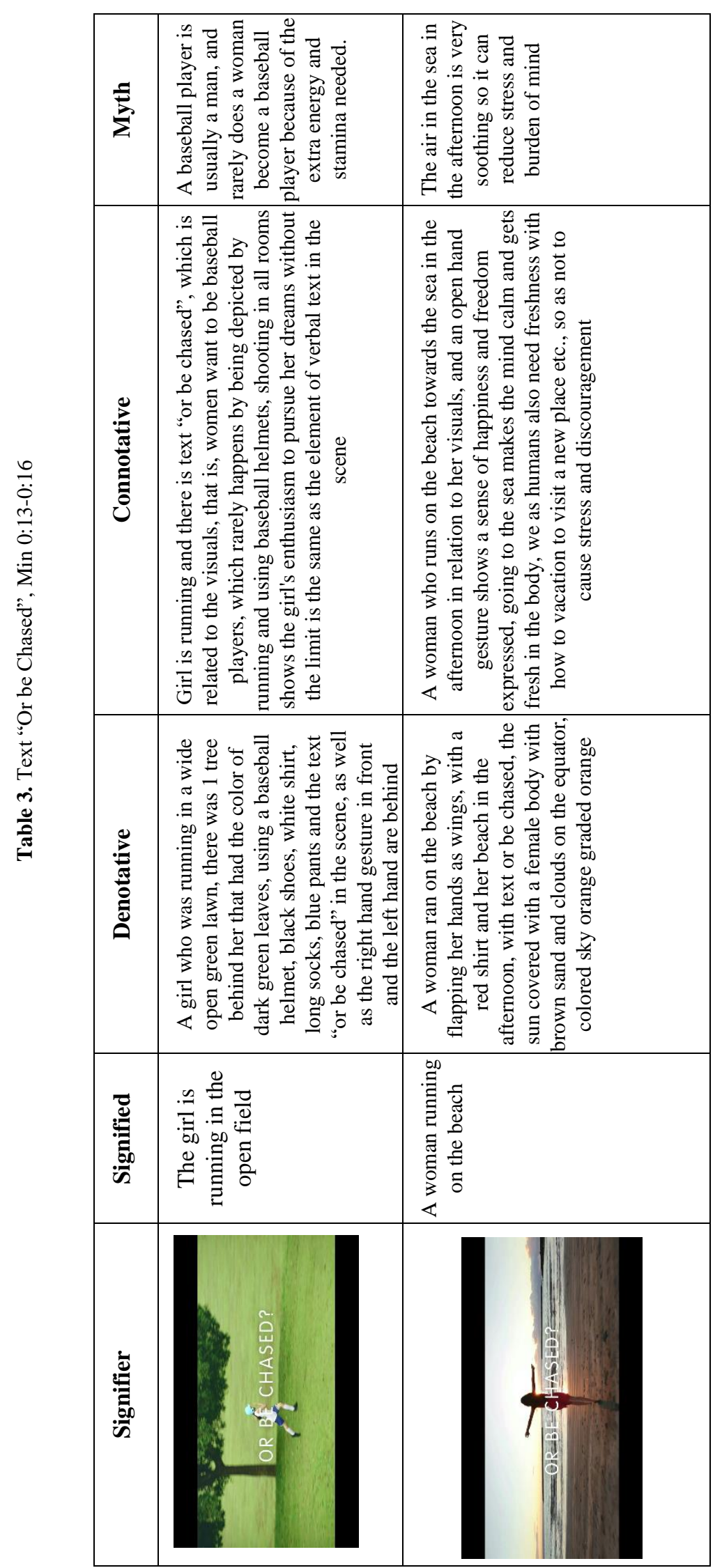




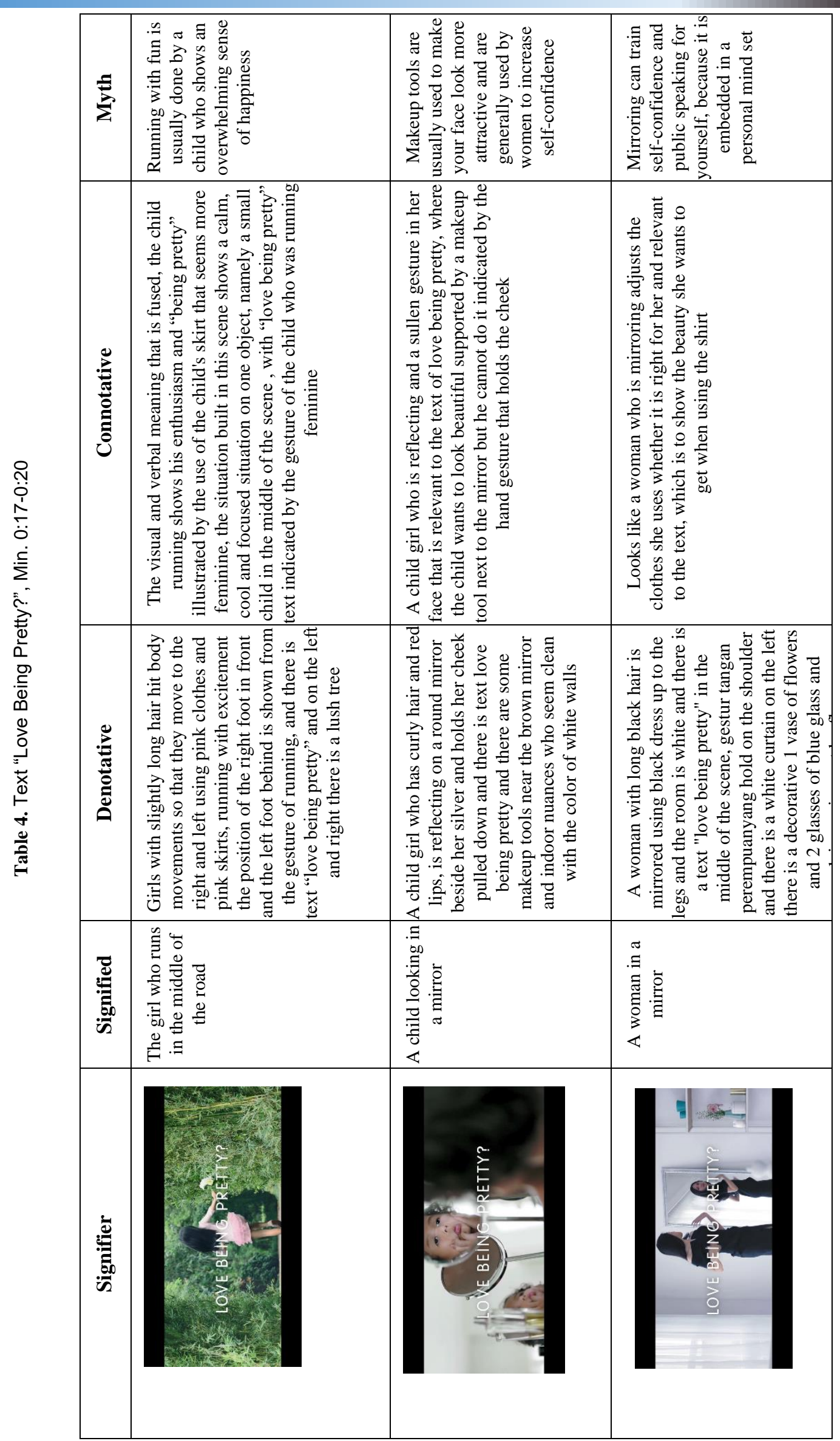




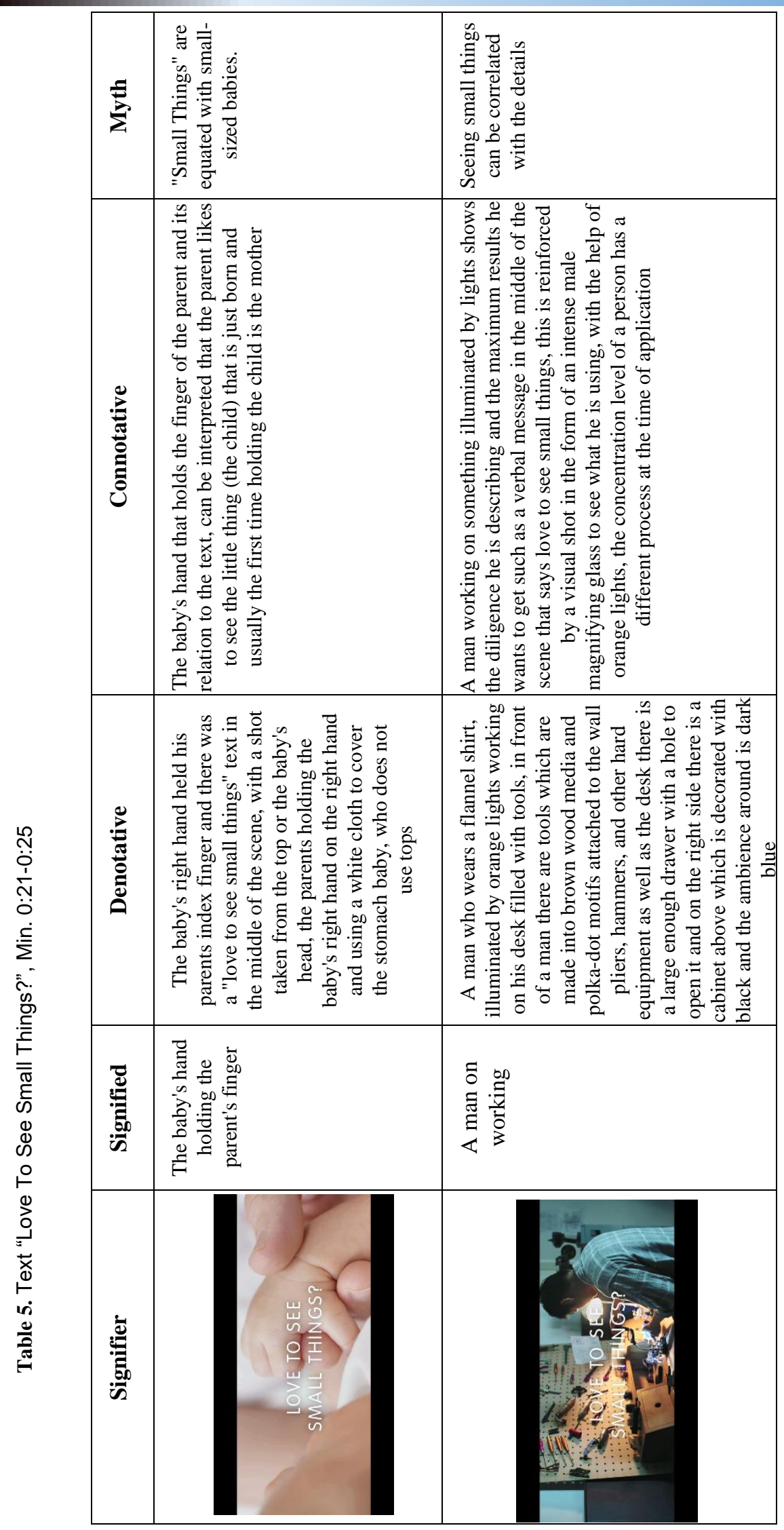




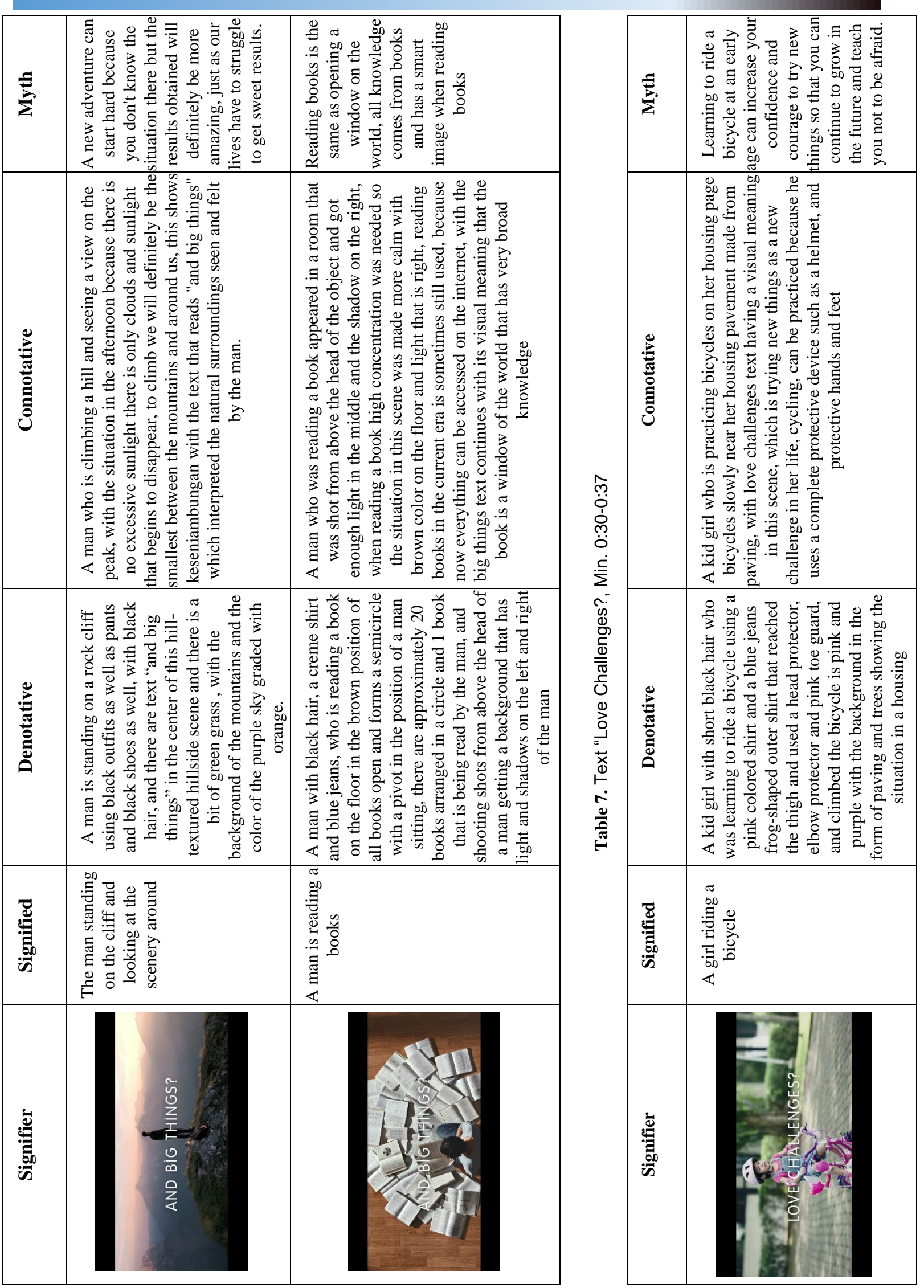



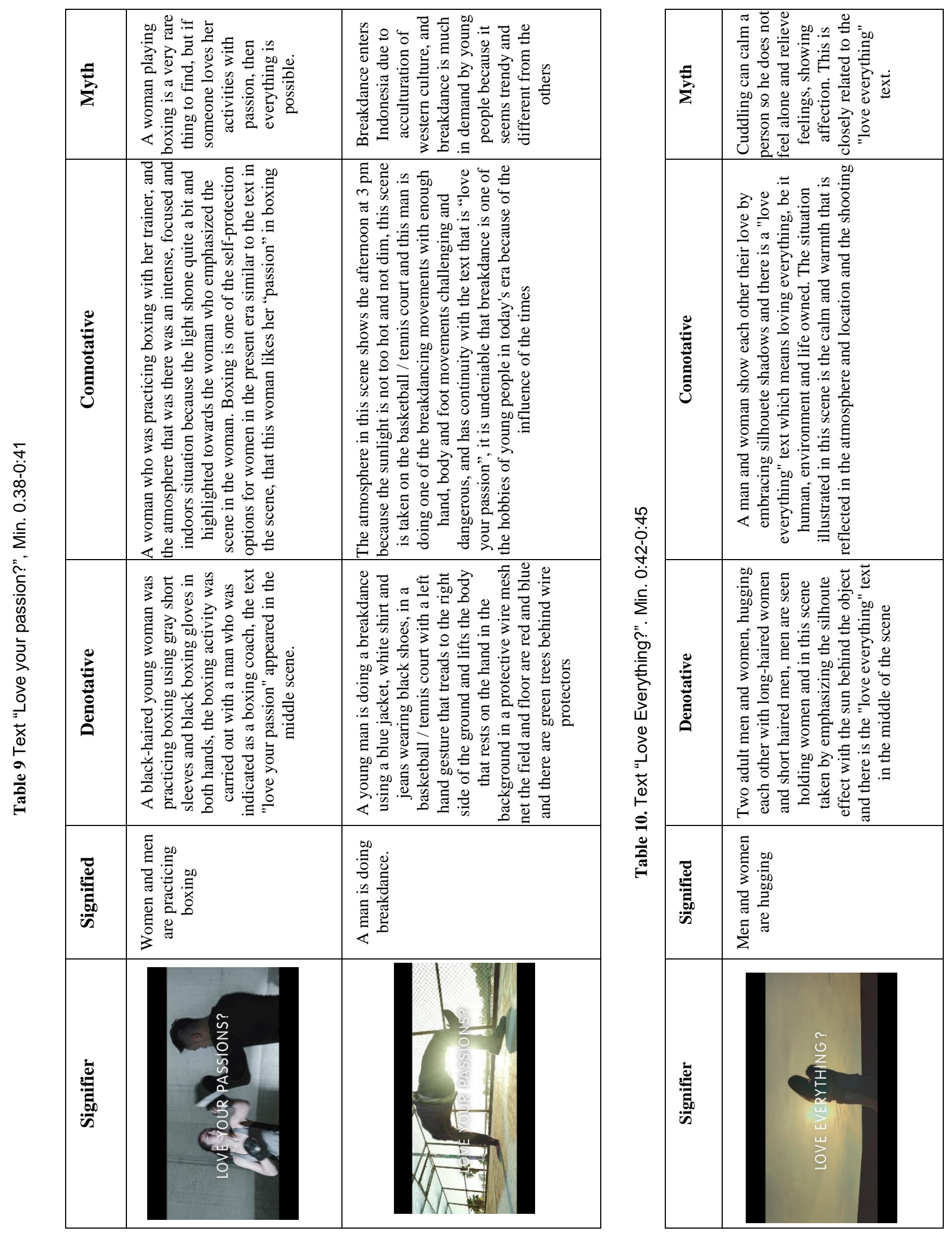


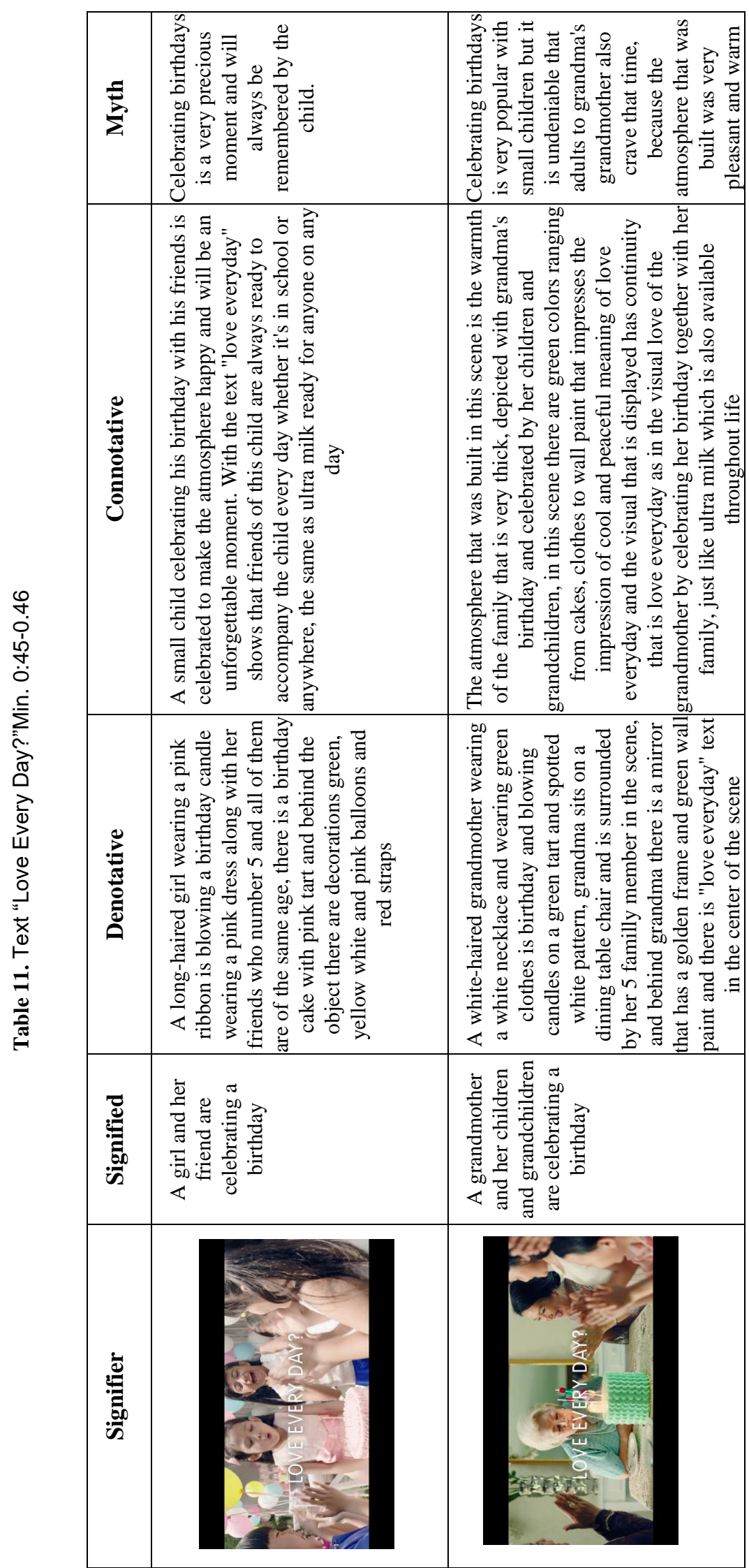




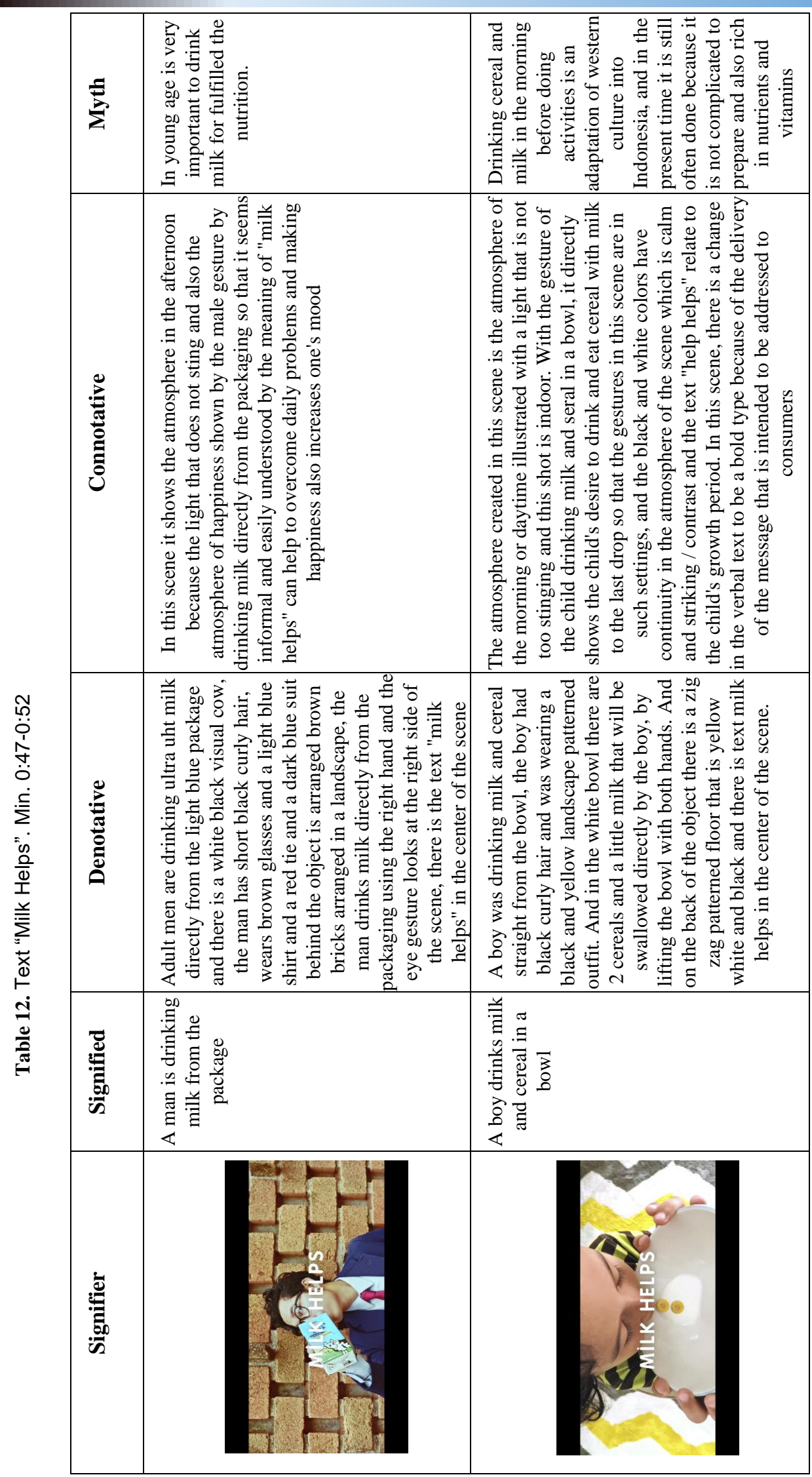




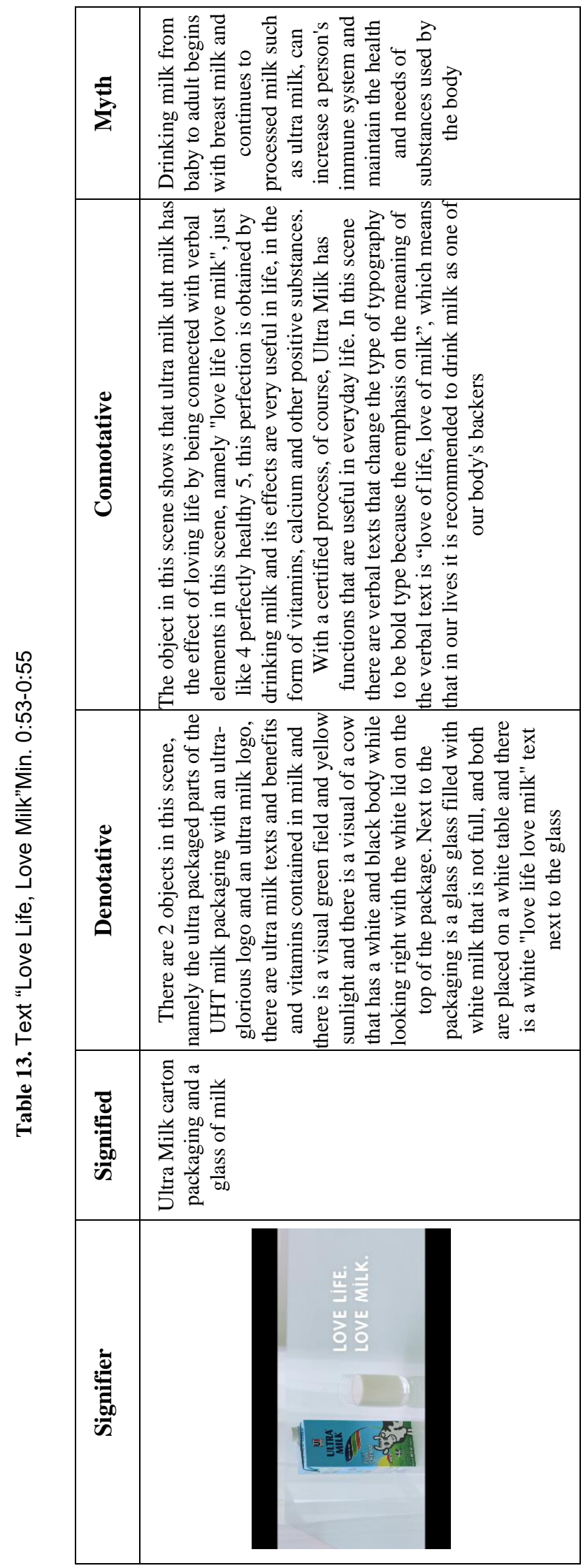




\section{Conclusion}

The overall meaning of the message from the UHT Ultra Milk "Love Life, Love Milk" advertising are invites consumers or potential consumers to be able to preserve the culture of drinking milk, from children to parents, and instill confidence for all consumers or prospective consumers to dare to struggle to achieve their dreams by not giving up and living a healthy and balanced life by drinking milk. Because milk has many benefits for life. Thus UHT Ultra Milk can be one of the choices of milk that is suitable for consumption, with the advertised media being raised to make consumers believe about the impact if you drink UHT Ultra Milk.

From this study concluded that UHT Ultra Milk "Love Life, Love Milk" having the implicit message contained in this advertisement can be understood by several groups, because this advertising does not convey a clear message about what the advertisement means. So advertising consumers must think first about what is meant by the visuals taken in each scene and also the verbal text that appears in some scenes, what the meaning is contained and what is the correlation between visual and verbal texts.

With the launch of this ad on youtube television and social media, UHT Ultra Milk tried to change the mindset of the community as consumers to prioritize maintaining the health and balance of the body by drinking milk. As well as inviting consumers to not be afraid of pursuing their dreams, both young people and parents. Therefore UHT Ultra Milk "Love Life, Love Milk" is a promotional advertisement for a product that can also lead to public service advertisements that encourage consumers to keep struggling to achieve dreams don't look at age, this advertisement according to researchers has enough potential to influence consumers.

\section{References}

Coelho, Denis \& Figueiredo, J. (2010). Semiotic Analysis in Perspective. Design Principles and Practices.

Duncan, T. (2005). Principle Of Advertising and IMC. International. Edition. Second Edition. New York: McGrawHill

Holt, M. (2017). Semiotics and Design: Towards an Aesthetics of the Artificial. The Design Journal, 20, S322-S341.

Lal, Ruhi \& Vats, A. (2016). Advertising Effectiveness On Television And Attitude Of Youth. AheadInternational Journal of Recent Research Review, 1, 60-65.

Najafi, Farzaneh \& Abbas, M. (2014). A Study of the Semiotic Understanding of Land Art. Asian Social Science.

Sutherland, M. \& A. K. S. (2005). Advertising and The Mind of The Consumer Bagaimana Mendapatkan Untung Berlipat Lewat Iklan yang Tepat. Translator: Setia Bangun. Jakarta: PT. Gramedia Pustaka.

Verlegh, Peeter \& Fransen, Marieke \& Kirmani, A. (2015). Persuasion in advertising: When does it work, and when does it not? International Journal of Advertising.

Zoest, A. van. (1993). Semiotika: Tentang Tanda, Cara Kerjanya dan Apa yang Kita Lakukan Dengannya. Jakarta: Yayasan Sumber Agung. 